ABDEL AZIZ S.FOUDA ${ }^{1 *}$, SALAH M.RASHWAN ${ }^{2}$, NADIA F. ABD EL-AAL ${ }^{2}$, NAGLAA H. RAMADAN'

${ }^{1}$ Department of Chemistry, Faculty of Science, El-Mansoura

University, El-Mansoura-35516, Egypt, ${ }^{2}$ Department of Chemistry, Faculty of Science, Suez Canal University, Ismailia, Egypt
Scientific paper

ISSN 0351-9465, E-ISSN 2466-2585

UDC: 620.197 .3

doi:10.5937/ZasMat1602326F

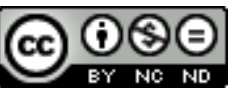

Zastita Materijala $57(2)$

$326-338$ (2016)

\title{
Unused Augmentin Drug as save corrosion inhibitor for $\alpha$-brass in Nitric acid solution
}

\begin{abstract}
Unused Augmentin was investigated as save corrosion inhibitor for $\alpha$-brass in nitric acid solution by different monitoring techniques. The results showed the variation in inhibition performance of the drug with varying concentrations and temperatures. The maximum efficiency was found to be $93.6 \%$ at 300 ppm concentration of the drug for the immersion period of 3 hours at $40^{\circ} \mathrm{C}$. Temkin was tested to describe the adsorption behavior of the drug on $\alpha$-brass surface. Potentiodynamic polarization study clearly revealed that this drug acts as mixed type inhibitor. The results of the electrochemical impedance study showed a decrease in double layer capacitance and increase in charge transfer resistance. Chemical adsorption mechanism is proposed from the calculated thermodynamic parameters for the studied drug. The results of various techniques showed good agreements with each other.
\end{abstract}

Keywords: Corrosion inhibition, a-brass, unused Augmentin, Temkin isotherm, $\mathrm{HNO}_{3}$

\section{INTRODUCTION}

Alpha brass has an excellent electrical and thermal conductivity, good corrosion resistance and mechanical workability. It is widely used in the construction of heat exchangers, condensers, and valve systems. They are mostly used in building fronts, rails, lock bodies, door knobs etc. Corrosive acid medium is generally utilized as a part of the industry. The most vital zones of use are acid pickling, industrial acid cleaning, acid decaling and oil well acidizing [1,2]. Corrosion inhibitors are introducing to lower the rates of corrosion on $\alpha$ brass in this acidic solution [3-8]. An inhibitor is an substance that used to reduce the corrosion rate by the adsorption mechanism [9-10]. Many inhibitors have been prepared or selected from compounds existing, and the best inhibitors are those that contain $\pi$-electron donation while others might be obtain by naturally extracts from compounds occurring [11-13]. Many organic compounds are referred to be relevant as corrosion inhibitors for $\alpha$ brass [14,15]. However, just a couple non-harmful and eco-friendly has been obtaining as inhibitors

\footnotetext{
${ }^{*}$ Corresponding author: Abdel Aziz S. Fouda

E-mail: asfouda@hotmail.com

Paper received: 19.03.2016.

Paper accepted: 27.04.2016.

Paper is available on the website: www.idk.org.rs/journal
}

for corrosion. Succinic acid, Tryptamine, Sulfamethoxazole, Cefatrexyl and L-ascorbic acid were obtained to be good inhibitors for acidic medium. Dithiobiurets displayed the best execution towards the corrosion of mild steel in $\mathrm{HCl}$ arrangements indicated less poisonous quality [16-21]. The four antibacterial drugs, Amoxicillin, Flucloxacillin, Cloxacillin, and Ampicillin have investigated as inhibitors for the aluminum corrosion [22]. The inhibition action of the four antibacterial drugs was given by blocking the metal via presence of insoluble complexes on the surface of aluminum. Because of the fact that most of the chemical compounds that prevent the corrosion of metal and alloys are toxic, and thus pose threat both for human health and environment, their usage is limited. For this reason, several authors reported the use of natural products as corrosion inhibitors [23]. Also, some authors used drugs which are derivatives of natural substance like penicillin as a green corrosion inhibitors for various metals and alloys [24-32].

In the present work, authors investigate the corrosion protection activity of unused Augmentin by using chemical and electrochemical methods.

\section{MATERIALS AND METHODS}

\subsection{Materials and solutions}

The chemical composition of the used a-brass in weight \% is: $\mathrm{Pb} 0.029$, Fe $0.002, \mathrm{Zn} \mathrm{32.68,} \mathrm{Cu}$ 
the rest. The solution of the corrosive medium 0.5 $\mathrm{M} \mathrm{HNO}_{3}$ was prepared by dilution of analytical reagent nitric acid (70\%) with bi-distilled water and its concentration was checked by restandarazied solution of $\mathrm{NaOH}$. One gm of unused Augmentin was dissolved in one liter of bi-distilled water to yield 1000 ppm and the concentration used (50300 ppm) was obtained by dilution by bi-distilled water. The structure of the unused Augmentin (Amoxicillin/ Clavulanic acid) drug is shown below with molecular structure $\mathbf{C}_{24} \mathbf{H}_{28} \mathbf{N}_{4} \mathbf{O}_{10} \mathbf{S}$ and molecular weight $564.5 \mathrm{~g} / \mathrm{mol}$ :
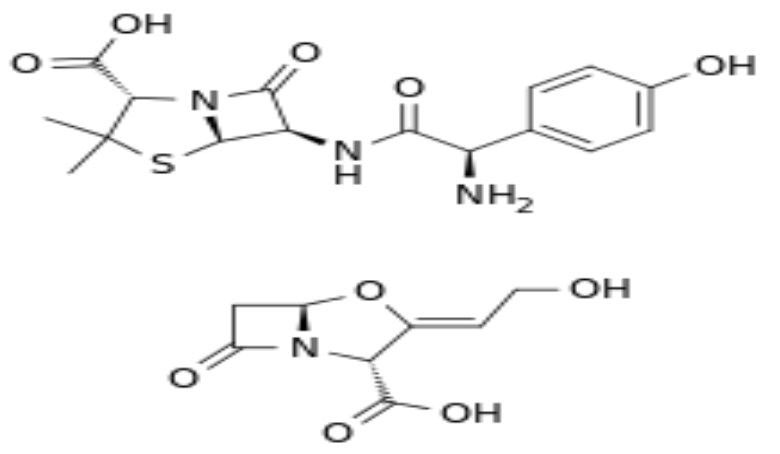

(2S,5R,6R)-6-[[(2R)-2-amino-2-(4hydroxyphenyl)acetyl]amino]-3,3-dimethyl-7-oxo-4thia-1-azabicyclo[3.2.0]heptane-2-carboxylic acid;(2R,3Z,5R)-3-(2-hydroxyethylidene)-7-oxo-4oxa-1-azabicyclo[3.2.0]heptane-2-carboxylic acid.

\subsection{Chemical measurements}

Seven test pieces of $\alpha$-brass were cut into $2 \times 2$ $x 0.2 \mathrm{~cm}$. They were abraded in presence of various grades of emery papers up to 1200 grit size (coarse grades was utilized first and then finer grades were final), washed with bi-distilled water then acetone and finally dried between filter papers and weighed. The specimens were immersed in test solution. Weight loss method was done for 3 hours at the temperature range $25-40^{\circ} \mathrm{C}$ by immersing $\alpha$-brass pieces into $100 \mathrm{ml}$ acid medium in presence and absence of unused Augmentin drug with different times, then weighed accurately again. The main weight loss at each time for seven samples was taken. The weight loss was obtained by:

$$
\Delta W=W_{B}-W_{A}
$$

where $W_{B}$ and $W_{A}$ is the weight of metal before and after exposure to the corrosive solution respectively. The percentage of inhibition efficiency $(\% \mathrm{IE})$ and the degree of surface coverage $(\theta)$ of the investigated compounds by the adsorbed molecules were calculated by the following equations:

$$
\begin{aligned}
& \% I E=\left[1-\left(\Delta W_{\text {inh }} / \Delta W_{\text {free }}\right)\right] \times 100 \\
& \Theta=\left[1-\left(\Delta W_{\text {inh }} / \Delta W_{\text {free }}\right)\right]
\end{aligned}
$$

where $\Delta \mathrm{W}_{\text {free }}$ and $\Delta \mathrm{W}_{\text {inh }}$ is the weight loss of metal per unit area in the absence and presence of inhibitors respectively at given time period and temperature.

$$
\text { C.R. }=\Delta W / A D T
$$

where C.R is corrosion rate in $\mathrm{mg} \mathrm{cm}^{-2} \mathrm{~min}^{-1}, A$ is area in $\mathrm{cm}^{2}, \mathrm{D}=$ density of the metal in $\mathrm{g} \mathrm{cm}^{-3}$ and $T$ is the time in min.

\subsection{Electrochemical measurements}

Electrochemical measurements were done by using typical three electrodes cell, first working electrode $\left(1 \mathrm{~cm}^{2}\right)$ of the a-brass, second (SCE) saturated calomel electrode as a reference electrode and a platinum foil $\left(1 \mathrm{~cm}^{2}\right)$ as a counter electrode. All the experiments were done in open system. All potential values were reported versus SCE. Tafel polarization curves were obtained by the electrode potential changing from -0.6 to $0.5 \mathrm{~V}$ vs. SCE at open potential circuit with a scan rate of $1 \mathrm{mVs}^{-1}$. The corrosion current is done by extrapolation of cathodic and anodic Tafel lines to obtain $\log \mathrm{i}_{\text {corr }}$ and $\left(\mathrm{E}_{\text {corr }}\right)$. The impedance method was done and interpreted depend on the equivalent circuit. The data which obtained from the analysis of Nyquist curves are $\left(R_{\mathrm{ct}}\right)$ the charge transfer resistance and the double layer capacity $C_{\text {dl }}$. Electrochemical frequency modulation (EFM) was carried out using two frequencies 2 and $5 \mathrm{~Hz}$. The larger peaks were used to measure the Tafel slopes $\left(B_{c}, B_{a}\right)$, causality factors CF-2\&CF-3 and $i_{\text {corr }}$.

All the electrochemical studies were performed using Gamry Instrument Series $\mathrm{G} 750^{\mathrm{TM}}$ Potentiostat/Galvanostat/ZRA with Gamry applications include DC105 software for potentiodynamic measurements, EFM140 software for EFM measurements, and EIS300 software for EIS measurements. Echem Analyst 5.5 Software installed in a laptop computer was used for graphing, plotting and fitting data.

\section{RESULTS AND DISCUSSION}

\subsection{Weight loss tests}

Figure1 shows plot of weight loss-time curves for a-brass corrosion in $0.5 \mathrm{M} \mathrm{HNO}_{3}$ containing different concentrations of unused Augmentin at $25^{\circ} \mathrm{C}$. From the plots, it is evident that the weight loss of $\alpha$-brass was decreased with increasing the concentration of the drug. The data of Table 1 represent the corrosion rates of $\alpha$-brass, \% IE and degree of surface coverage of unused Augmentin in $\mathrm{HNO}_{3}$ solution. The \% IE raises with higher concentration of the unused Augmentin [33] and the drug showed more than $87 \%$ inhibition efficiency and lowest corrosion rate at optimum 
concentration $300 \mathrm{ppm}$. This result is due to the coordination between the hetero atoms and $\alpha$-brass in the drug. Also it is obvious that the weight loss of $\alpha$-brass in the presence of this inhibitor varies linearly with time. This indicates the absence of oxide film on $\alpha$-brass surface. The inhibitory action of Augmentin against a-brass corrosion can be attributed to the adsorption of drug molecules on $\alpha$ brass surface, which limits the dissolution of the latter by blocking its corrosion sites and hence decreasing the weight loss [34].

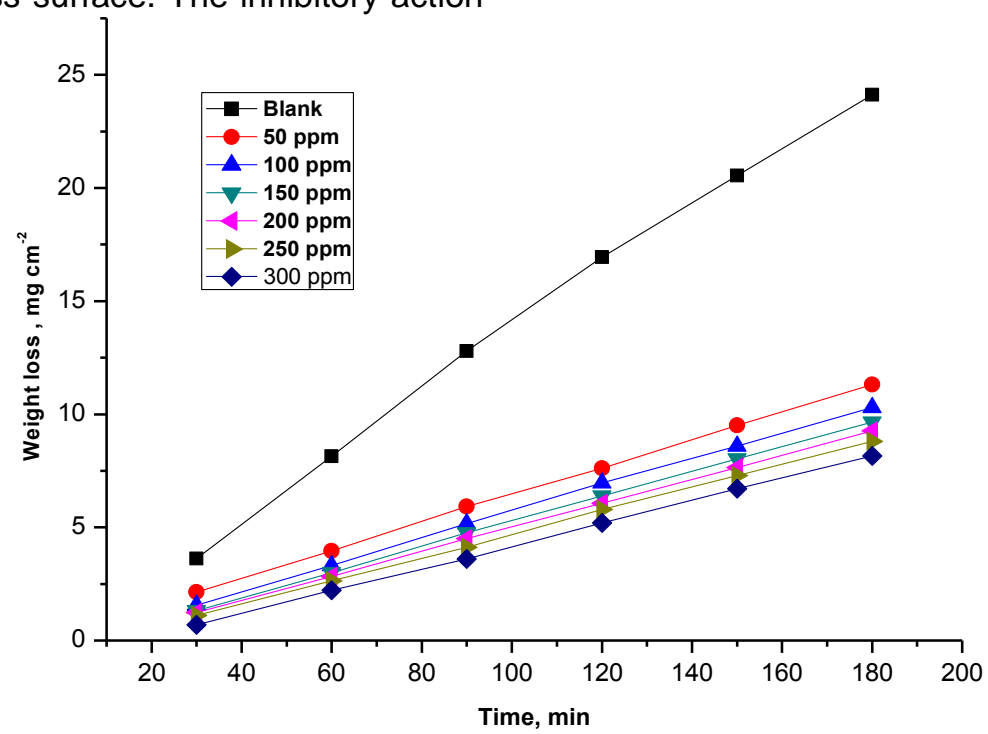

Figure 1 - Weight loss-time curves of $\alpha$-brass in $0.5 \mathrm{M} \mathrm{HNO}_{3}$ in the absence and presence of various concentrations of unused Augmentin at $25^{\circ} \mathrm{C}$

\subsection{Temperature effect on inhibition efficiency}

The data obtained in Table 1 showed the effect of temperature on \% IE and C.R. The obtained data revealed that, the inhibition efficiency increased with rise in temperature. This suggested that drug molecule is adsorbed on the a-brass surface chemically. The data of Tables 1 revealed that weight loss of $\alpha$-brass decreases with increasing the temperature indicating that the rate of corrosion of metal decreases with increasing the temperature. It is also clear that rate of corrosion of a-brass without and with Augmentin obeys Arrhenius type equation as it increases with raising solution temperature. The dependence of the rate of corrosion $\left(\mathrm{k}_{\text {corr }}\right)$ on the temperature can be expressed by Arhenius equation 2:

$$
i_{\text {corr }}=A \exp \left(-E_{a}^{*} / R T\right)
$$

where $\mathrm{A}=$ pre-exponential factor and $\mathrm{E}_{\mathrm{a}}{ }^{*}=$ apparent activation energy for corrosion process.

Arrhenius plots (Figure 2) show the corrosion of a-brass in $0.5 \mathrm{M} \mathrm{HNO}_{3}$ solution with and without different concentrations of unused Augmentin. The linear regression $\left(R^{2}\right)$ is close to 1 which led to that the corrosion of $\alpha$-brass in $0.5 \mathrm{M}$ acidic medium can be determined by using the kinetic model. Table 2 gives the data of $E_{a}{ }^{*}$, for inhibited Augmentin solution.
Table 1 - Corrosion Rate (C.R.) and inhibition efficiency (\% IE) at different concentrations and temperatures of unused Augmentin for the corrosion of $\alpha$-brass after 120 min immersion in $0.5 \mathrm{M} \mathrm{HNO}_{3}$

\begin{tabular}{|c|c|c|c|}
\hline \multirow{2}{*}{$\begin{array}{c}\text { Temp. } \\
{ }^{\circ} \mathrm{C}\end{array}$} & \multirow{2}{*}{$\begin{array}{c}\text { Conc. } \\
\text { ppm }\end{array}$} & \multicolumn{2}{|l|}{ Augmentin } \\
\hline & & $\mathrm{CR}\left(\mathrm{mg} \mathrm{cm} \mathrm{cmin}^{-1}\right) \times 10^{3}$ & $\%$ IE \\
\hline \multirow{6}{*}{25} & 50 & 30 & 78.4 \\
\hline & 100 & 26 & 81.1 \\
\hline & 150 & 25 & 82.5 \\
\hline & 200 & 23 & 83.9 \\
\hline & 250 & 20 & 85.9 \\
\hline & 300 & 17 & 87.7 \\
\hline \multirow{6}{*}{30} & 50 & 39 & 81.1 \\
\hline & 100 & 35 & 83.4 \\
\hline & 150 & 33 & 84.2 \\
\hline & 200 & 30 & 85.1 \\
\hline & 250 & 25 & 88.2 \\
\hline & 300 & 20 & 90.4 \\
\hline \multirow{6}{*}{35} & 50 & 45 & 83.1 \\
\hline & 100 & 39 & 85.4 \\
\hline & 150 & 35 & 87.0 \\
\hline & 200 & 32 & 88.1 \\
\hline & 250 & 26 & 90.5 \\
\hline & 300 & 21 & 92.0 \\
\hline \multirow{6}{*}{40} & 50 & 54 & 86.0 \\
\hline & 100 & 45 & 88.5 \\
\hline & 150 & 40 & 89.6 \\
\hline & 200 & 35 & 91.1 \\
\hline & 250 & 28 & 92.8 \\
\hline & 300 & 25 & 93.6 \\
\hline
\end{tabular}


Table 2 - Activation parameters for $\alpha$-brass corrosion in the absence and presence of various concentrations of drug in $0.5 \mathrm{M} \mathrm{HNO}_{3}$

\begin{tabular}{|c|c|c|c|}
\hline $\begin{array}{c}\Delta \mathrm{S}^{*},- \\
\mathrm{J} \mathrm{mol}^{-1} \mathrm{~K}^{-1}\end{array}$ & $\begin{array}{c}\Delta \mathrm{H}^{*}, \\
\mathrm{~kJ} \mathrm{~mol}^{-1}\end{array}$ & $\begin{array}{c}\mathrm{E}_{\mathrm{a}}{ }^{*}, \\
\mathrm{~kJ} \mathrm{~mol}^{-1}\end{array}$ & $\begin{array}{c}\text { Conc., } \\
\text { Ppm }\end{array}$ \\
\hline 97.2 & 49.2 & 51.4 & $\mathbf{0}$ \\
\hline 183.2 & 25.7 & 29.5 & 50 \\
\hline 195.1 & 24.3 & 26.3 & 100 \\
\hline 201.9 & 22.5 & 24.4 & 150 \\
\hline 214.8 & 17.9 & 20.7 & 200 \\
\hline 225.6 & 16.9 & 18.4 & 250 \\
\hline 228.5 & 16.3 & 17.1 & 300 \\
\hline
\end{tabular}

The data of this Table indicate that $\mathrm{E}_{\mathrm{a}}{ }^{*}$ values decreases in presence of drug than in its absence, this indicates that the drug molecules are adsorbed on a-brass surface chemically [35]. Entropy and Enthalpy of activation $\left(\Delta \mathrm{H}^{\star}, \Delta \mathrm{S}^{*}\right)$ of the process of corrosion were calculated from the transition state theory as given from eq. 6 (Table 2):

$k_{\text {corr }}=(R T / N h) \exp \left(\Delta S^{*} / R\right) \exp \left(-\Delta H^{*} / R T\right)$

Where $h$ is Planck's constant and $N$ is Avogadro's number. A plot of log $\left(\mathrm{k}_{\mathrm{corr}} / \mathrm{T}\right) \mathrm{vs}$. $1 / \mathrm{T}$ for a-brass with different concentrations of unused Augmentin gives straight lines as shown in Figure 3. Values of $\Delta \mathrm{H}^{*}$ are negative. This means that the activation process is an exothermic corrosion process. The entropy of activation $\Delta S^{\star}$ is large and negative. This implies that the activated complex represents association rather than dissociation step, i.e. decrease in disorder occurs when moving from reactants to the activated complex [36]. Figure 3 Transition-state for $\alpha$-brass corrosion $\left(\mathrm{k}_{\text {corr }} / \mathrm{T}\right)$ in $0.5 \mathrm{M} \mathrm{HNO}_{3}$ with and without unused different drug concentrations. Table 2 reported the parameters $\left(\Delta \mathrm{H}^{*}, \Delta \mathrm{S}^{*}\right)$ of Activation for $\alpha$-brass corrosion without and with various concentrations of unused drug.

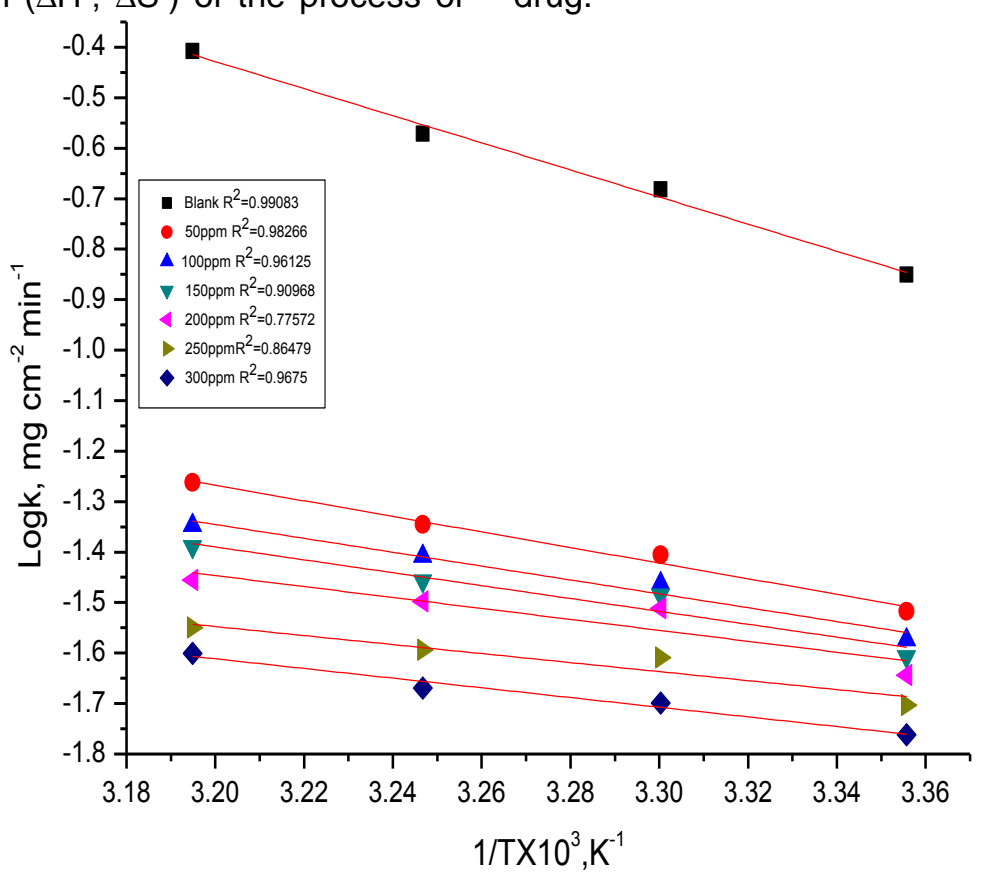

Figure 2 - Arrhenius plots for $\alpha$-brass corrosion rates ( $k_{\text {corr. }}$ ) after 120 minute of immersion in $0.5 \mathrm{M} \mathrm{HNO}_{3}$ in the absence and presence of various concentrations of the Augmentin

\subsection{Adsorption isotherms}

Adsorption isotherm values are vital to explain the mechanism of corrosion inhibition of organo electrochemical reactions. The all frequently used isotherms are Temkin isotherm (Figure 4). Thermodynamic parameters for the adsorption of investigated drug on a-brass surface at various temperatures were reported in Table 3. From Table 3 it was found that: The negative data of $\Delta G^{\circ}$ ads reflect that the adsorption of studied drug on $\alpha$ brass in $0.5 \mathrm{M} \mathrm{HNO}_{3}$ solution is spontaneous process [37]. The obtained values of $\Delta \mathrm{G}^{\circ}$ ads $(27.5$ $29.8 \mathrm{~kJ} \mathrm{~mol}^{-1}$ ) lead to the absorption of the drug on the $\alpha$-brass surface is mixed one (physisorption and chemisorptions).

Table 3 - Thermodynamic adsorption parameters from Temkin isotherm model for $\alpha$-brass in 0.5 M HNO3for unused Augmentin

\begin{tabular}{|c|c|c|c|c|}
\hline $\begin{array}{c}\text { Temp., } \\
\mathrm{K}\end{array}$ & $\begin{array}{c}\mathrm{K}_{\mathrm{ads}}, \\
\mathrm{M}^{-1}\end{array}$ & $\begin{array}{c}-\Delta \mathrm{G}_{\text {ads }}^{\circ} \\
\mathrm{kJ} \mathrm{mol}^{-1}\end{array}$ & $\begin{array}{c}-\Delta \mathrm{H}^{\circ} \text { ads } \\
\mathrm{KJ} \mathrm{mol}^{-1}\end{array}$ & $\begin{array}{c}\Delta \mathrm{S}^{\circ} \text { ads } \\
\mathrm{J} \mathrm{mol}^{-1} \mathrm{~K}^{-}\end{array}$ \\
\hline 298 & 1175 & 27.5 & & 173.4 \\
\hline 308 & 1187 & 29.4 & \multirow{2}{*}{24.2} & 176.8 \\
\hline 318 & 1676 & 29.3 & & 173.7 \\
\hline 328 & 1680 & 29.8 & & 172.5 \\
\cline { 1 - 2 } & & &
\end{tabular}




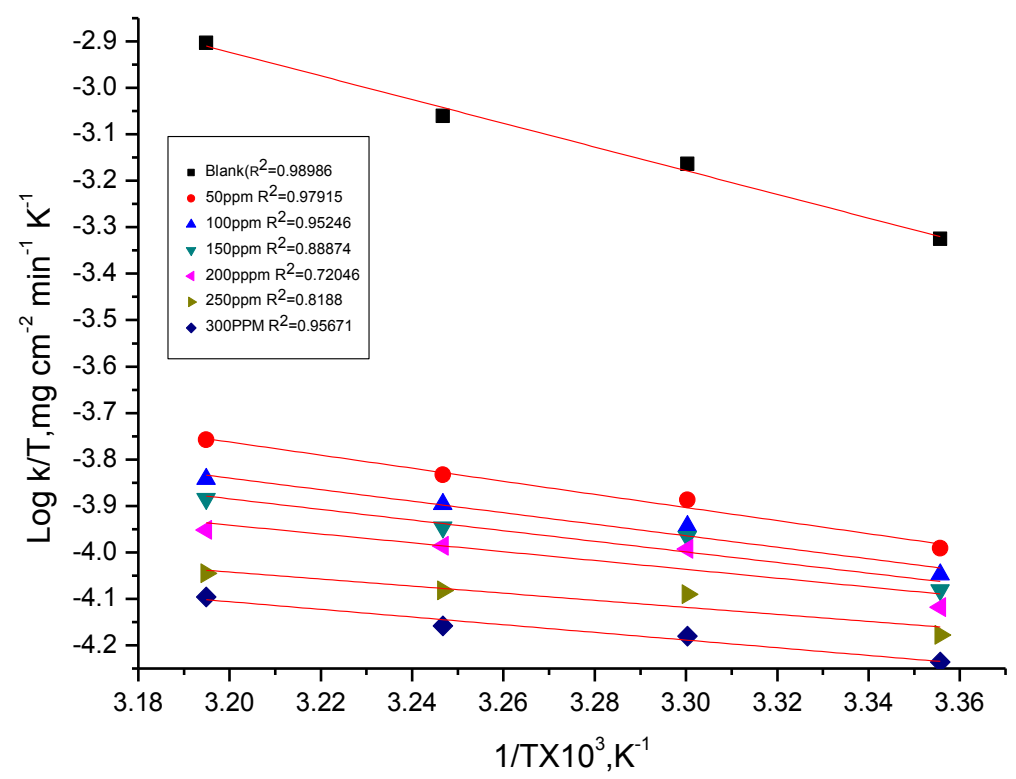

Figure 3 - Transition-state for $\alpha$-brass corrosion $\left(k_{\text {corr }} / T\right)$ in $0.5 \mathrm{M} \mathrm{HNO}_{3}$ in the absence and presence of various concentrations of the Augmentin

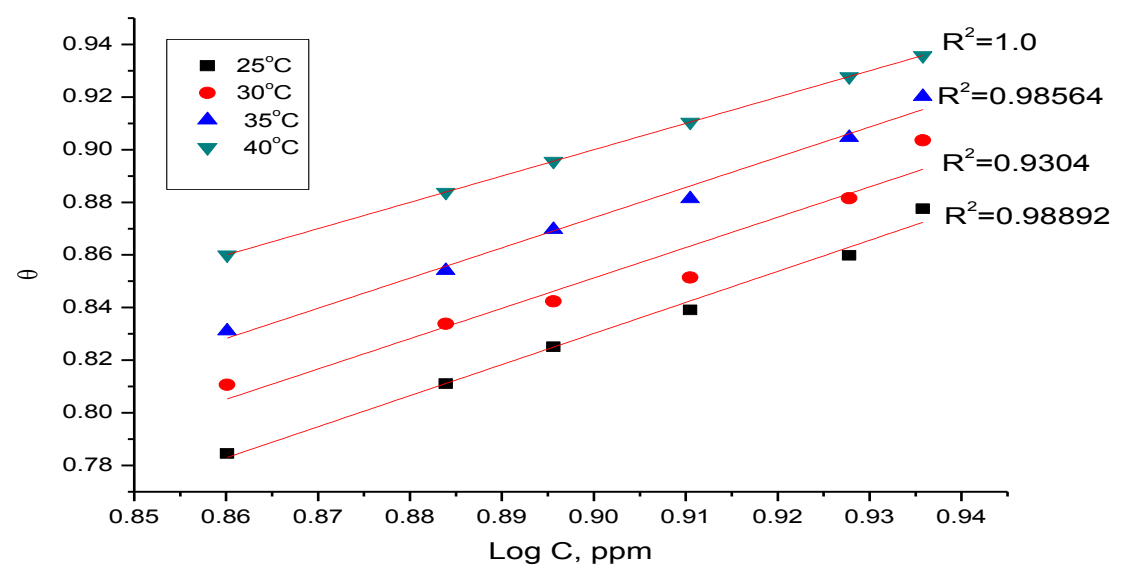

Figure 4 - Temkin isotherm of augmentin on a-brass surface in $0.5 \mathrm{M} \mathrm{HNO}_{3}$ at different temperatures

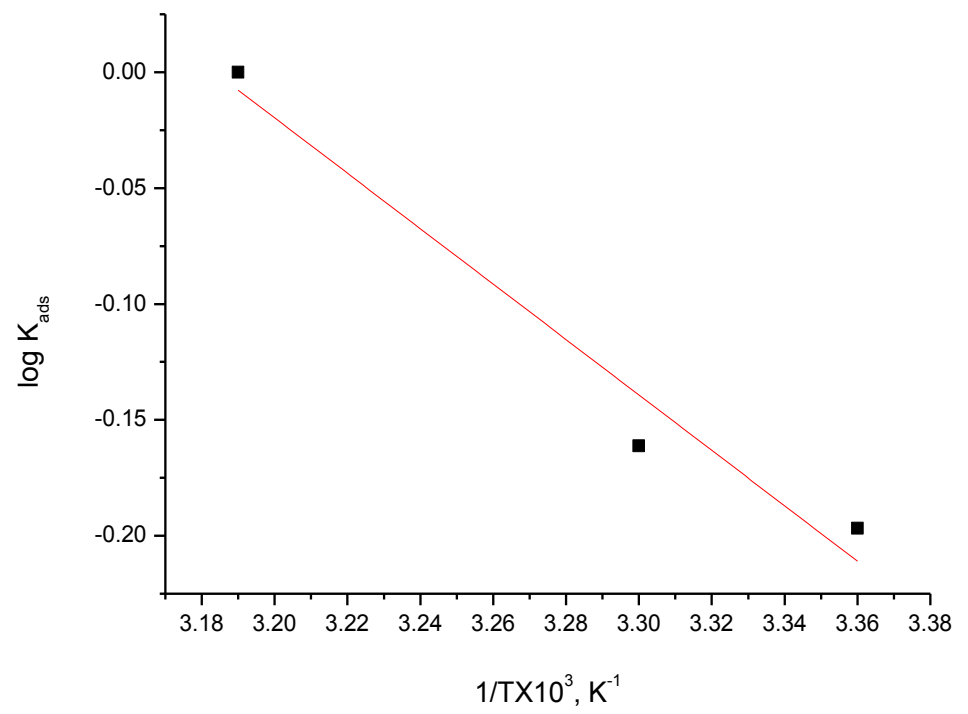

Figure 5 - Log $K_{\text {ads }} v s(1 / T)$ for the corrosion of unused drug on $\alpha$-brass surface in $0.5 \mathrm{M} \mathrm{HNO}_{3}$ at different temperatures 
Figure 5 shows the plot of log $\mathrm{K}_{\text {ads }}$ vs. $1 / \mathrm{T}$, $\Delta \mathrm{H}^{\circ}$ ads was obtained from the slope of this line. $\Delta S^{\circ}$ ads values were obtained from the basic equation $\left(\Delta \mathrm{G}^{\circ}{ }_{\text {ads }}=\Delta \mathrm{H}^{\circ}{ }_{\text {ads }}{ }^{-} \mathrm{T} \Delta \mathrm{S}^{\circ}{ }_{\text {ads }}\right)$ The negative sign of $\Delta \mathrm{H}^{\circ}$ ads reveals, an exothermic adsorption process which suggested either chemisorptions or physisorption while endothermic is attributed to chemisorption [38]. The positive values of $\Delta S^{\circ}$ ads can be related to the lower in the entropy of the solvent and this led to more entropy positive. It is also discussed that the rise of the disorderness in presence of the drug, this is may be due to more water molecules, which can be desorbed from the a-brass surface by one drug molecule. The experimental data give good curves fitting for the applied adsorption isotherm. $\mathrm{K}_{\mathrm{ads}}$ value increases with the increase of temperature from 25 to $40^{\circ} \mathrm{C}$.

\subsection{Potentiodynamic polarization tests}

Polarization methods were done in order to gain knowledge of the kinetics of the cathodic and anodic reactions. Figure 5 presents the data of the effect of Augmentin on the cathodic and anodic polarization curves of $\alpha$-brass in $0.5 \mathrm{HNO}_{3}$. Both the cathodic and anodic reactions were suppressed in presence of investigated drug, which led to lowering the anodic dissolution of $\alpha$-brass and also retarded the evolution of hydrogen reaction. Electrochemical corrosion kinetics parameters, i.e. corrosion potential $\left(E_{\text {corr }}\right)$, Tafel slopes $\left(B_{\mathrm{a}}, B_{\mathrm{c}}\right)$ and $\left(i_{c o r r}\right)$ given from the extrapolation of the polarization curves, were given in Table 4. The parallel cathodic Tafel lines in Figure 6 lead to the evolution of hydrogen is activation controlled and the lower mechanism is not affected with inhibitor. The region between linear part of cathodic and anodic branch of polarization diagrams becomes wider as put the Augmentin to the acid solution. Similar results were obtained in the literature [39]. The data of $B_{a}$ and $B_{c}$ changed slightly with rise inhibitor concentration indicated the influence of these compounds on the kinetics of metal dissolution and of hydrogen evolution.

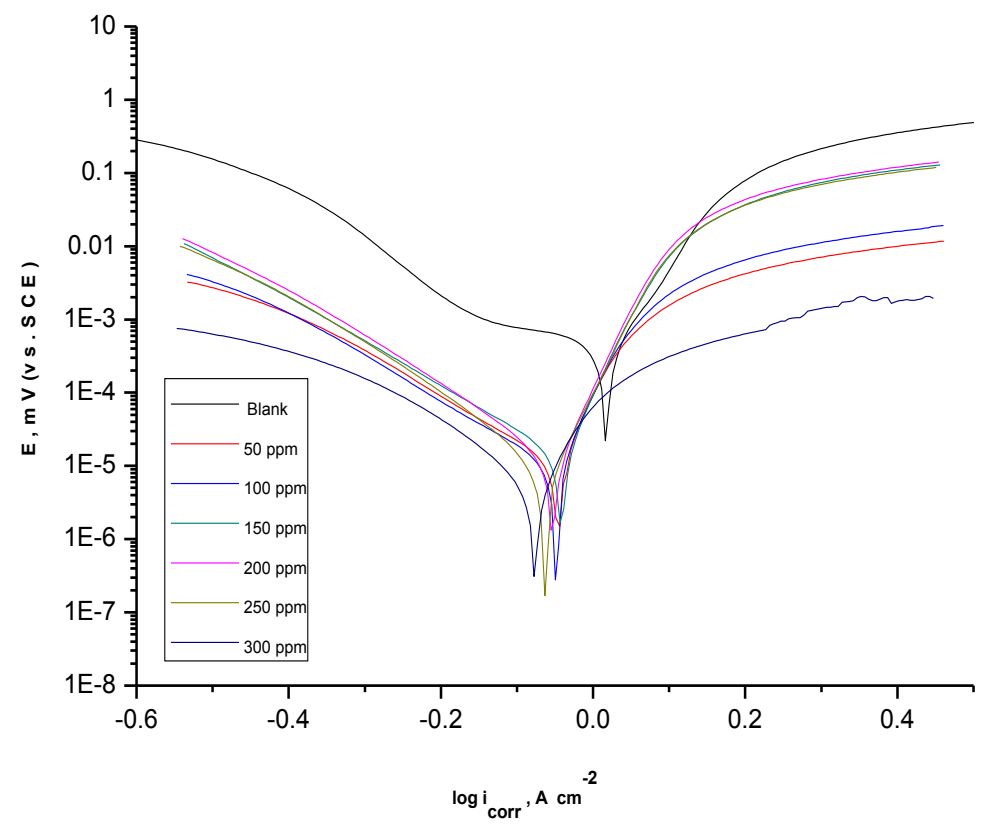

Figure 6 - Potentiodynamic polarization curves for the dissolution of a-brass in $0.5 \mathrm{M} \mathrm{HNO}_{3}$ in the absence and presence of different concentrations of Augmentin at $25^{\circ} \mathrm{C}$

Table 4 - Effect of concentrations of various compounds on the free corrosion potential $\left(E_{\text {corr }}\right)$, corrosion current density $\left(i_{\text {corr }}\right)$, Tafel slopes $\left(\beta_{c}, \beta_{a}\right)$, corrosion rate $\left(k_{\text {corr }}\right)$, degree of surface coverage $(\theta)$, and inhibition efficiency (\%IE) of $\alpha$-brass in $0.5 \mathrm{M}$ of $\mathrm{HNO}_{3}$ at $25^{\circ} \mathrm{C}$

\begin{tabular}{|c|c|c|c|c|c|c|c|}
\hline$\%$ IE & $\Theta$ & $\begin{array}{c}\text { C.R. } \\
\mathrm{mmy}^{-1}\end{array}$ & $\begin{array}{c}\beta_{\mathrm{c}}, \\
\mathrm{mV} \mathrm{dec}^{-1}\end{array}$ & $\begin{array}{c}\beta_{\mathrm{a}} \\
\mathrm{mV} \mathrm{dec}^{-1}\end{array}$ & $\begin{array}{c}\mathrm{i}_{\text {corr }} \\
\mathrm{mA} \mathrm{cm}^{-2}\end{array}$ & $\begin{array}{c}-E_{\text {corr }} \\
\mathrm{mVvs} \mathrm{SCE}\end{array}$ & $\begin{array}{c}\text { Conc. } \\
\mathrm{ppm}\end{array}$ \\
\hline---- & --- & 133.3 & 19 & 99 & 136 & 17 & 0.0 \\
\hline 87.7 & 0.877 & 7.527 & 19 & 84 & 16.7 & 47 & 50 \\
\hline 88.8 & 0.888 & 7.498 & 17 & 52 & 15.3 & 42 & 100 \\
\hline 89.7 & 0.897 & 6.885 & 17 & 54 & 14.0 & 53 & 150 \\
\hline 92.3 & 0.923 & 5.186 & 17 & 63 & 10.4 & 49 & 200 \\
\hline 92.9 & 0.929 & 4.564 & 20 & 74 & 9.61 & 77 & 250 \\
\hline 93.8 & 0.938 & 4.117 & 14 & 56 & 8.38 & 63 & 300 \\
\hline
\end{tabular}


Due to the found of some active sites, such as hetero-atoms, aromatic rings in the Augmentin for making adsorption, they may work as adsorption inhibitors. Being absorbed on the alloys, Augmentin controlled the cathodic and anodic reactions during corrosion process. The structure and functional groups of the Augmentin play important roles during the adsorption process. On the other hand, an electron transfer obtains during adsorption of the neutral organic compounds at surface of alloy [40]. As in the Table 5, the studied inhibitor lowers both cathodic and anodic currents with a slow shift in potential of corrosion $(47 \mathrm{mV})$. According to Ferreira and others [41], the studied inhibitor is mixed-type inhibitor. The results which were given from Tafel polarization yield good agreement with the data given from mass reduction method. The \% IE and coverage surface $(\theta)$ were measure utilized Equation.6:

$$
\% I E=\theta \times 100=\left[1-\left(i_{\text {corr }} / i_{\text {corr }}^{\circ}\right)\right] \times 100
$$

where $\mathrm{i}_{\text {corr }}$ and $\mathrm{i}_{\text {corr }}$ are the current densities without and with inhibitor, respectively.

Table 5 - EIS parameters for the corrosion of $\alpha$ brass in $0.5 \mathrm{M} \mathrm{HNO}_{3}$ in the absence and presence of different concentrations of investigated drug at $25^{\circ} \mathrm{C}$

\begin{tabular}{|c|c|c|c|c|}
\hline $\begin{array}{c}\text { Conc., } \\
\text { ppm }\end{array}$ & $\begin{array}{c}\mathrm{C}_{\mathrm{dl}}, \\
\mu \mathrm{F} \mathrm{cm}^{-2}\end{array}$ & $\begin{array}{c}\mathrm{R}_{\mathrm{ct},} \\
\mathrm{ohm} \mathrm{\textrm {cm } ^ { 2 }}\end{array}$ & $\Theta$ & $\% \mathrm{IE}$ \\
\hline Blank & 9.7410 & 116 & ---- & --- \\
\hline 50 & 6.5000 & 714 & 0.838 & 83.8 \\
\hline 100 & 0.3259 & 717 & 0.839 & 83.9 \\
\hline 150 & 0.1682 & 915 & 0.874 & 87.4 \\
\hline 200 & 0.1389 & 939 & 0.877 & 87.7 \\
\hline 250 & 0.1249 & 1160 & 0.900 & 90.0 \\
\hline 300 & 0.0627 & 1320 & 0.912 & 91.2 \\
\hline
\end{tabular}

\subsection{EIS Tests}

Tests Nyquist curves of metal in inhibited and uninhibited acid solutions containing different concentrations of unused augmentin are presented in Figure 7. EIS spectra data consists of one depressed capacitive loop. The higher diameter of loop given in acidic medium with Augmentin indicated the inhibition of corrosion of $\alpha$-brass. The high frequency capacitive loop may give the charge transfer reaction.

Corrosion kinetic parameters derived from EIS method are given in Table 6. $\left(R_{c t}\right)$ charge transfer resistance and $\left(\mathrm{C}_{\mathrm{dl}}\right)$ given from EIS method as described elsewhere [42]. It is apparent from Table 7 that the impedance of the inhibited system amplified with the inhibitor the $\mathrm{C}_{\mathrm{dl}}$ data lower with augmentin. This lower in $C_{d l}$ data from a lower in local dielectric constant and/or an higher in the thickness of the double layer, given that inhibitor molecules inhibit the iron corrosion by adsorption on metal/acid interface [43]. The lower in Nyquist loop is a feature for solid electrodes and often lead to as frequency remove and given the roughness and other inhomogeneities of the solid electrode [44]. Figure 8 showed the electrical equivalent circuit employed to analyze the impedance spectra. Excellent fit with this model was obtained for all experimental data. The surface coverage $(\theta)$ and $\%$ IE were measure utilized Equation. 7:

$$
\% I E=\theta \times 100=\left[1-\left(R_{c t} / R_{c t}{ }^{\circ}\right)\right] \times 100
$$

where $R^{\circ}{ }_{c t}$ and $R_{c t}$ are the charge transfer resistances without and with Augmentin inhibitor, respectively.

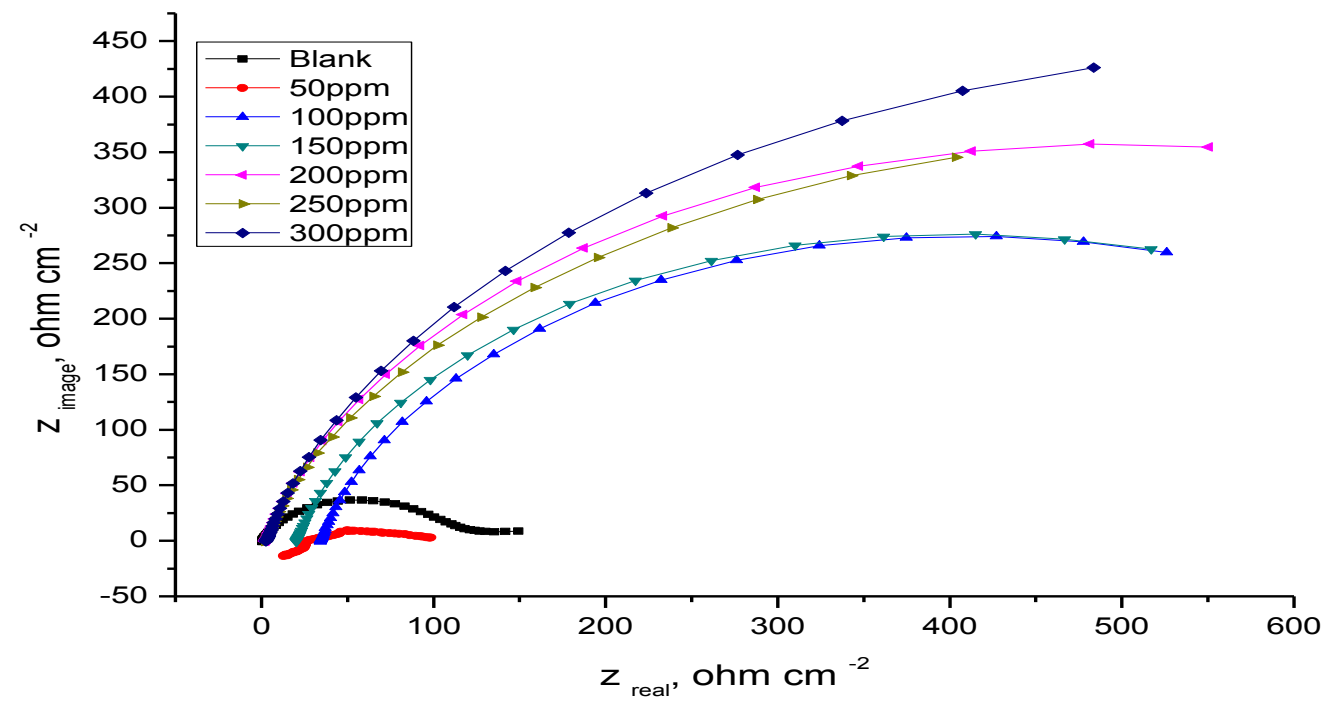

Fig. 7a) 


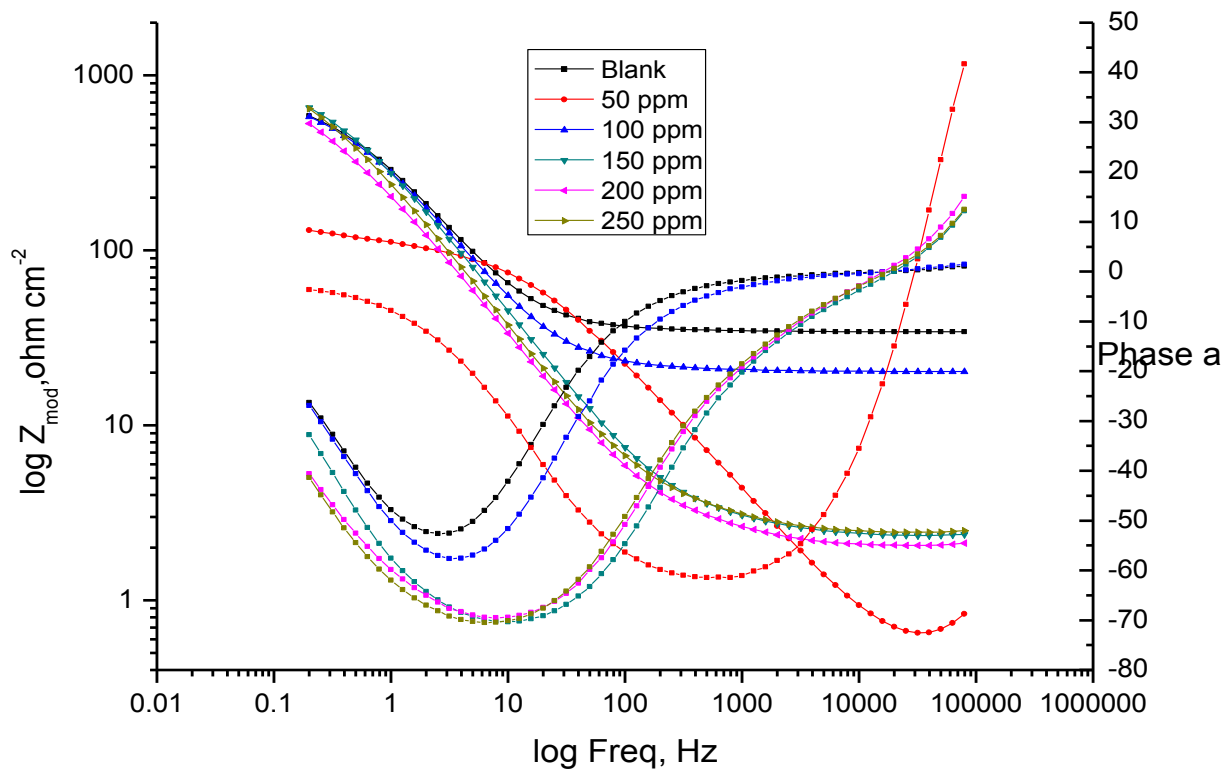

Fig $7 b)$

Figure 7 - EIS Nyquist plots (a) and Bode plots (b) for alpha brass in $0.5 \mathrm{MHNO}_{3}$ in the absence and presence of different concentrations of augmentin at $25^{\circ} \mathrm{C}$

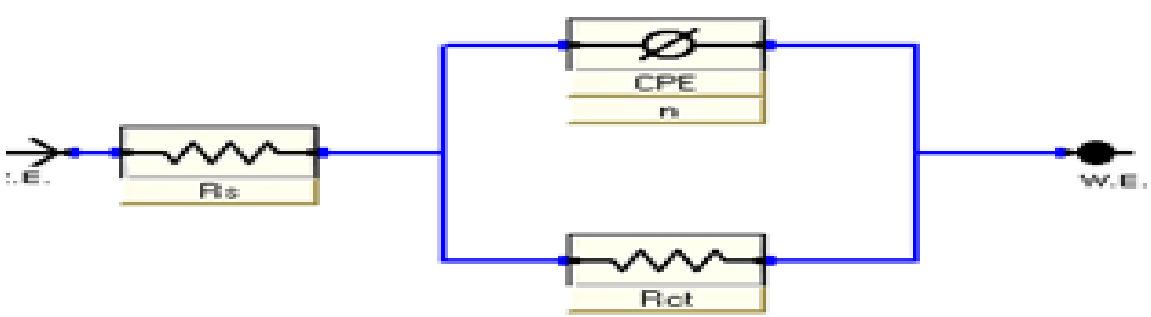

Figure 8 - Electrochemical equivalent circuits used to fit the impedance measurements that include a solution resistance $\left(R_{s}\right)$, a constant phase element $(C P E)$ and a polarization resistance or charge transfer $\left(R_{c t}\right)$.

Table 6 - Electrochemical kinetic parameters obtained from EFM technique for $\alpha$-brass in $0.5 \mathrm{M} \mathrm{HNO}_{3}$ in the absence and presence of different concentrations of unused augmentin drug

\begin{tabular}{|c|c|c|c|c|c|c|c|c|}
\hline $\begin{array}{c}\text { Conc } \\
\mathrm{ppm}\end{array}$ & $\begin{array}{c}\mathrm{i}_{\text {corr, }} \\
\mu \mathrm{Acm}^{-2}\end{array}$ & $\begin{array}{c}\beta_{\mathrm{c},} \\
\mathrm{mVdec}^{-1}\end{array}$ & $\begin{array}{c}\beta_{\mathrm{a},} \\
\mathrm{mVdec}^{-1}\end{array}$ & CF-2 & CF-3 & $\begin{array}{c}\text { C.R }, \\
\mathrm{mpy}\end{array}$ & $\Theta$ & $\% \mathrm{IE}$ \\
\hline 0.0 & 175.8 & 110 & 170 & 1.926 & 3.12 & 69.5 & - & - \\
\hline 50 & 41.98 & 60 & 130 & 2.087 & 3.593 & 20.47 & 0.761 & 76.1 \\
\hline 100 & 37.71 & 60 & 140 & 1.969 & 3.113 & 17.01 & 0.785 & 78.5 \\
\hline 150 & 34.88 & 60 & 130 & 1.961 & 3.588 & 16.07 & 0.802 & 80.2 \\
\hline 200 & 31.95 & 60 & 130 & 1.991 & 2.284 & 15.46 & 0.818 & 81.8 \\
\hline 250 & 26.14 & 60 & 120 & 1.940 & 2.775 & 13.72 & 0.851 & 85.1 \\
\hline 300 & 20.91 & 110 & 170 & 1.877 & 2.692 & 13.12 & 0.881 & 88.1 \\
\hline
\end{tabular}

Table 7 - Surface composition (wt \%) of alpha brass before and after immersion in $0.5 \mathrm{M} \mathrm{HNO}_{3}$ without and with $300 \mathrm{ppm}$ of Augmentin at $25^{\circ} \mathrm{C}$

\begin{tabular}{|l|c|c|c|c|c|c|c|c|}
\hline \multicolumn{1}{|c|}{ (Mass \%) } & $\mathrm{Cu}$ & $\mathrm{Zn}$ & $\mathrm{Fe}$ & $\mathrm{C}$ & $\mathrm{O}$ & $\mathrm{Al}$ & $\mathrm{As}$ & $\mathrm{Si}$ \\
\hline Free & 60.78 & 32.72 & 0.79 & 3.48 & 1.13 & 0.70 & 0.40 & ---- \\
\hline Blank & 54.57 & 25.78 & 0.78 & 10.41 & 7.85 & ---- & 0.61 & ---- \\
\hline Augmentin & 38.10 & 20.21 & ----- & 28.82 & 12.53 & ---- & ---- & 0.35 \\
\hline
\end{tabular}




\subsection{EFM Tests}

A nondestructive corrosion method likes EIS; it is a small signal technique. Unlike EIS, two waves (at various frequencies) are occurring to the cell simultaneously. The causality factors which given a check internal on the quality of the EFM method, given verified of data lead to higher EFM strength [45]. The spectrum of EFM is named the intermediation in figure 9. The spectra contain current responses assigned for harmonical and intermediation peaks of current. The biggest peaks were utilized to measure the current corrosion. The $\%$ IE measured by Equation 6 rise with higher the inhibitor concentrations studied. Intermodulation spectra obtained from EFM measurements were constructed for $\alpha$-brass acidic solution as a function of $300 \mathrm{ppm}$ of Augmentin at $25^{\circ} \mathrm{C}$. Each spectrum is a current response as a frequency. Data not shown here. Corrosion kinetic parameters, namely current corrosion density ( $i_{\text {corr }}$, Tafel constants $\left(B_{a}\right.$, $B_{c}$ ) and causality factors (CF-2, CF-3) were listed Table 6 as a function of concentrations of investigated drug at $25^{\circ} \mathrm{C}$. The causality factors in Table 7, which are very close to theoretical data towards to the EFM theory, The standard values for CF-2 and CF-3 are 2 and 3 [46]. The data obtained from mass reduction, electrochemical frequency, potentiodynamic polarization and impedance techniques are in a good agreement but it is of interest to note that, the data of \% IE given by electrochemical techniques are bigger than those obtained by mass reduction measurements; this may be due to the fact that the electrochemical methods were obtain by freshly prepared solutions.

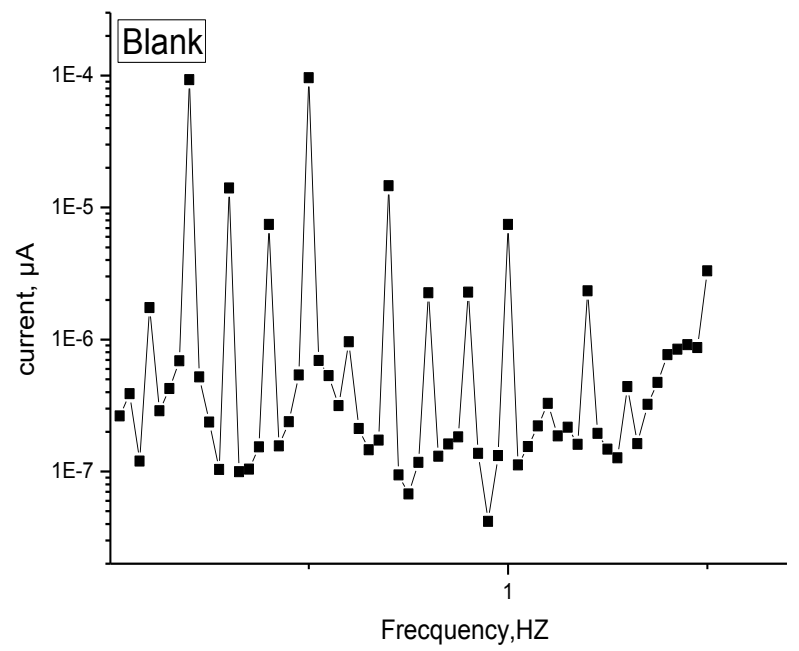

Figure 9 - Intermodulation spectra for $\alpha$-brass in $0.5 \mathrm{M} \mathrm{HNO}_{3}$

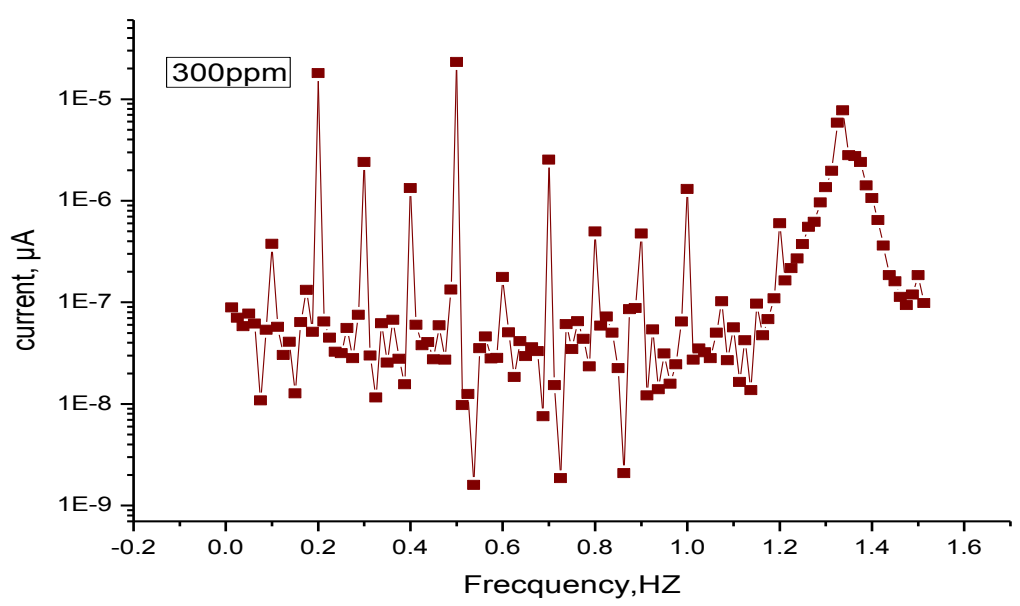

Figure 10 - Intermodulation spectra for alpha brass alloy in $0.5 \mathrm{M} \mathrm{HNO}_{3}+300 \mathrm{ppm}$ of unused Augmentin

\subsection{Surface Examinations}

\subsubsection{Scanning electron microscopy (SEM) studies}

Figure 11 represents the micrograph obtained of $\alpha$-brass samples after exposure to $0.5 \mathrm{M} \mathrm{HNO}_{3}$ for one day immersion. It is clear that alpha brass alloy surfaces suffer from severe corrosion attack. Figure 12 reveals the surface on alpha brass alloy after exposure to $0.5 \mathrm{M} \mathrm{HNO}_{3}$ solution containing $300 \mathrm{ppm}$ drug compound. It is important to stress out that when the compound is present in the solution, the morphology of alpha brass alloy surfaces are quite different from the previous one, the specimen surfaces were smoother. We noted the formation of a film which is distributed in a random way on the whole surface of the alpha brass alloy. This may be interpreted as due to the adsorption of the drug compound on the alpha brass alloy surface incorporating into the passive film in order to block the active site present on the alpha brass alloy surfaces. Or due to the involvement of inhibitor molecules in the interaction with the reaction sites of alpha brass alloy surface, resulting in a decrease in the contact between alpha brass and the aggressive medium and sequentially exhibited excellent inhibition effect. 


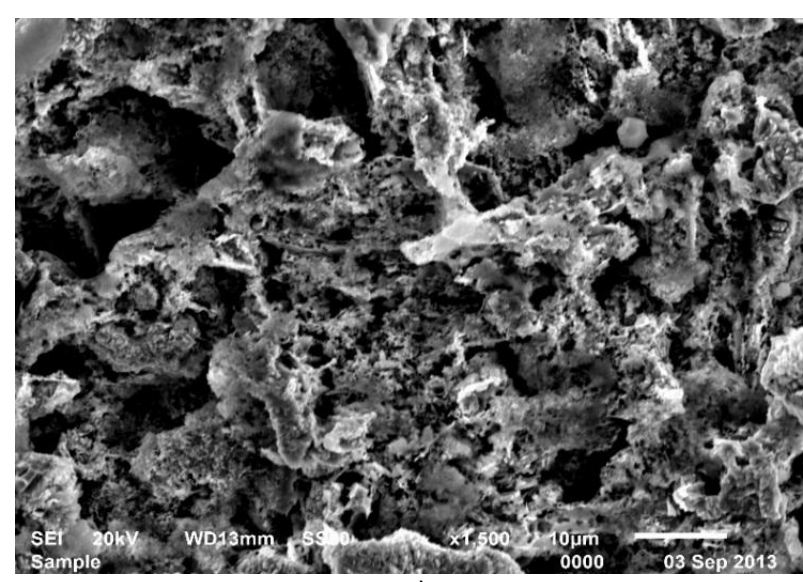

a)

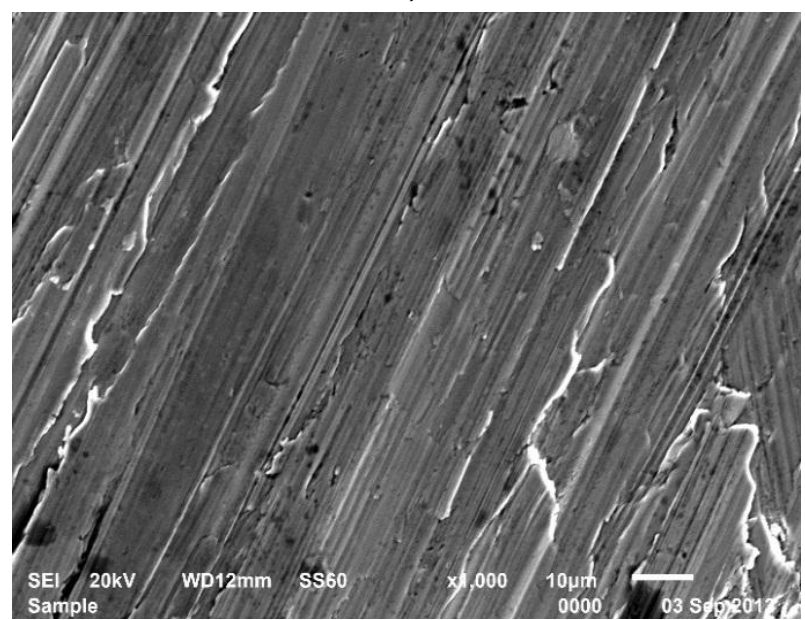

b)

Figure 11 - SEM micrographs of alpha brass surface (a) before of immersion in $0.5 \mathrm{M} \mathrm{HNO}_{3}$, (b) after $24 \mathrm{~h}$ of immersion in $0.5 \mathrm{M} \mathrm{HNO}_{3}$.

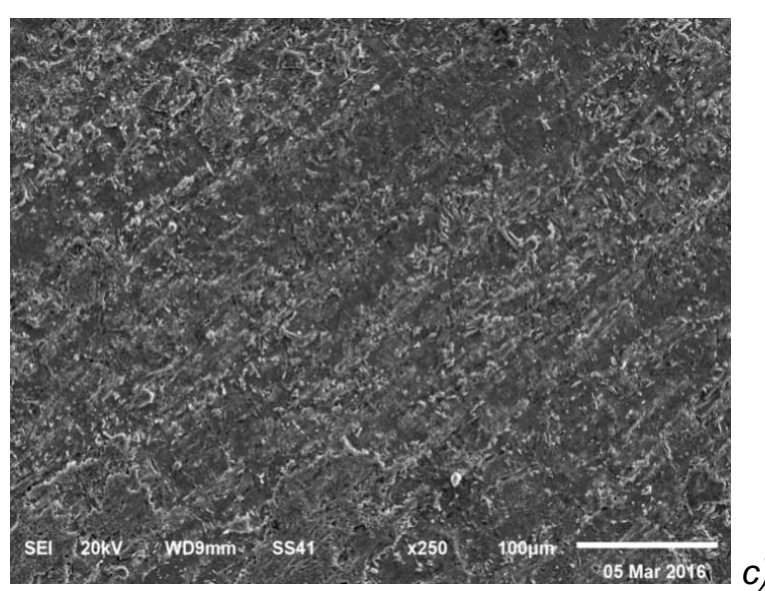

Figure 12 - (C) after $24 \mathrm{~h}$ of immersion in 0.5M $\mathrm{HNO}_{3}+300$ ppm augmentin.

\subsubsection{Energy Dispersion Spectroscopy (EDX)} Studies

The EDS spectra were used to determine the elements present on the surface of $\alpha$-brass and after one day of exposure to the uninhibited and inhibited $0.5 \mathrm{M} \mathrm{HNO}_{3}$. Figure13 shows the EDX analysis result on the composition of alpha brass only without the acid and inhibitor treatment. The EDX analysis indicates that only carbon and oxygen were detected, which shows that the passive film contained $\mathrm{CaCo}_{3}$ and $\mathrm{SiO}_{3}$. Figure14 portrays the EDX analysis of $\alpha$-brass in $0.5 \mathrm{M}$ $\mathrm{HNO}_{3}$ only and in the presence of 300 ppm M of drug compounds. The spectra show additional lines, demonstrating the existence of $C$ (owing to the carbon atoms of drug compound). These data shows that the carbon and $\mathrm{N}$ materials covered the specimen surface.

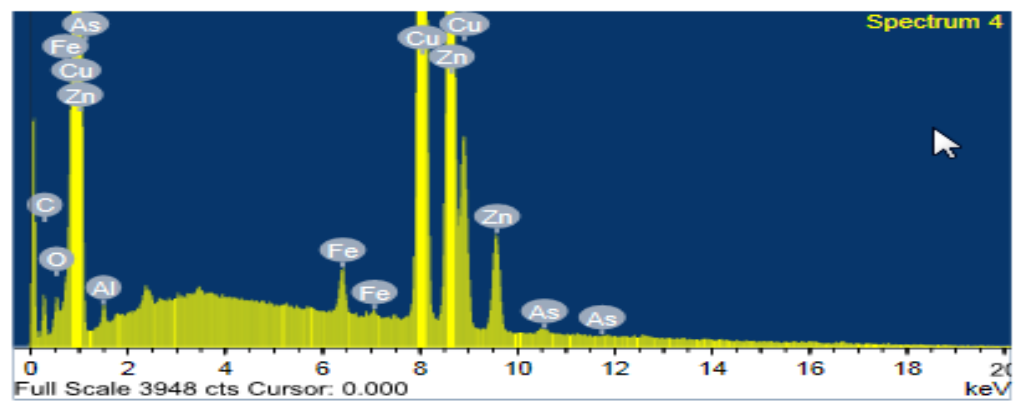

a)

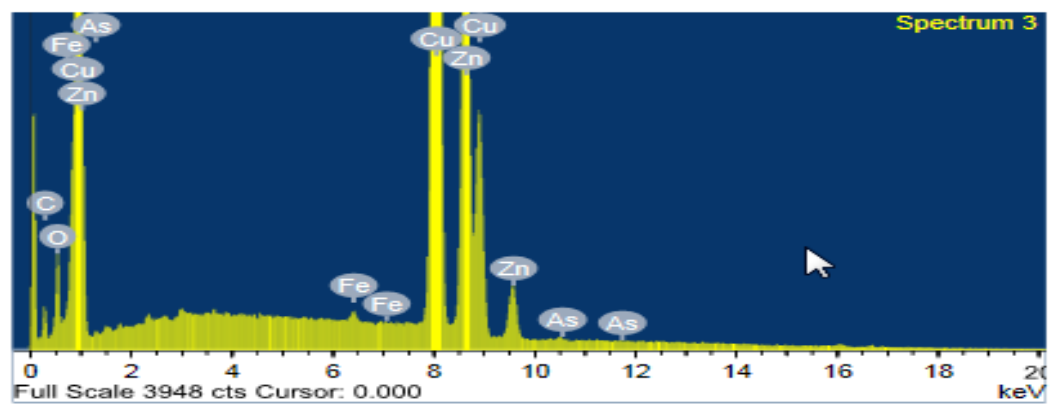

b)

Figure 13 - EDX spectra of alpha brass surface (a) before of immersion in $0.5 \mathrm{M} \mathrm{HNO}_{3}$,

(b) after $24 \mathrm{~h}$ of immersion in $0.5 \mathrm{M} \mathrm{HNO}_{3}$. 


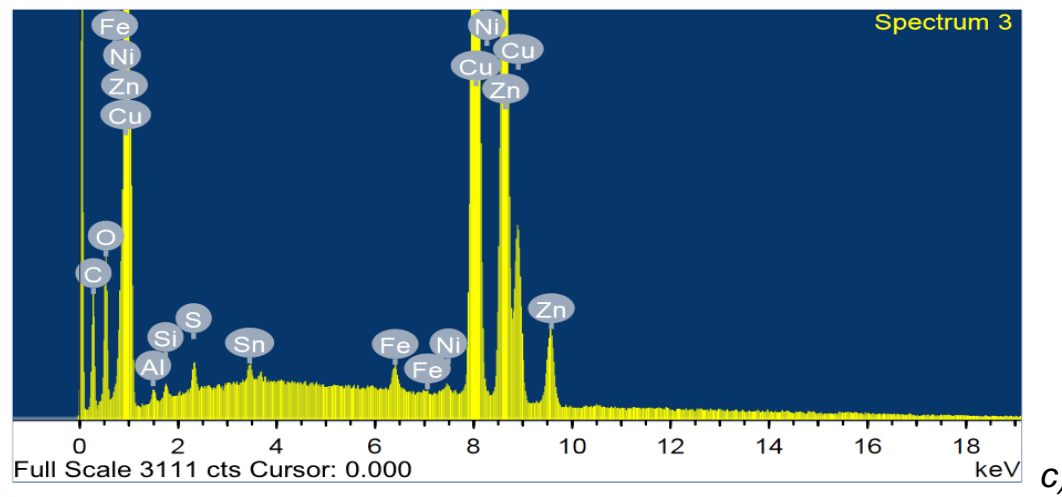

Figure 14 - EDX spectra of alpha brass (c) After 24 h of immersion in $0.5 \mathrm{MHNO}_{3}+300$ ppm Augmentin

\subsection{Mechanism of corrosion inhibition}

It is generally, assumed that the adsorption of the inhibitors at the metal / solution interface is the first step in the action mechanism of the inhibitors in aggressive acid media. Four types of adsorption may take place during inhibition involving drug molecules at the metal / solution interface: i) Electrostatic attraction between charged molecules and charged metal ii) Interaction of unshared electrons pairs in the molecule with the metal iii) Interaction of $\pi$ electrons with the metal vi) A combination of the above [47].

In acidic solutions, transition of metal/solution interface is attributed to the adsorption of the inhibitor molecules at the metal/solution interface, forming a protective film. The rate of adsorption is usually rapid and hence, the reactive metal surface is shielded from the acid solutions [48]. The adsorption of an inhibitor depends on its chemical structure, its molecular size, the nature and charged surface of the metal and distribution of charge over the whole inhibitor molecule. The exact nature of the interaction between a metal surface and a drug compound depends on the relative coordinating strength towards the given metal of the particular groups present [49] generally, two modes of adsorption were considered. In one mode, the neutral molecules of drug can be adsorbed on the surface of a-brass through the chemisorption mechanism, involving the displacement of water molecules from the $\alpha$-brass surface and the sharing electrons between the hetero-atoms and a-brass. The inhibitor molecules can also adsorb on the $\alpha$ brass surface on the basis of donor-acceptor interactions between $\pi$ - electrons of the heterocyclic ring and vacant d-orbitals of copper surface. In another mode, since it is well known that the $\alpha$ brass surface bears positive charge in acidic solutions [50], so it is difficult for the protonated drugs adsorbed through electrostatic interactions between the positively charged molecules and the negatively charged metal surface covered with $\mathrm{NO}_{3}^{-}$ions.

\section{CONCLUSIONS}

The unused Augmentin drug establishes a very good inhibition for a-brass in $\mathrm{HNO}_{3}$ solution. Unused Augmentin drug inhibits a-brass corrosion by adsorption on its surface. Adsorption of the unused Augmentin drug fits a Temkin isotherm model. The effect of temperature on corrosion inhibition efficiency of the inhibitor has been investigated, showing that the inhibition efficiency increases with increasing temperature. Double layer capacitance decreases with respect to blank solution when the drug is added. Polarization data showed that the investigated drug acts as mixedtype inhibitor in $0.5 \mathrm{M} \mathrm{HNO}_{3}$. The negative values of $\Delta G^{\circ}$ ads show the spontaneity and strongly adsorbed of this drug on the $\alpha$-brass surface. The values of inhibition efficiencies obtained from the different independent quantitative techniques used are in good agreement and showed the validity of the results.

\section{REFERENCES}

[1] D.P.Schweinsberg, G.A.George, A.K.Nanayakkara, D.A.Steinert (1988) The protective action of epoxy resins and curing agents-inhibitive effects on the aqueous acid corrosion of iron and steel, Corrosion science, 28 (1),33-42.

[2] I.L.Rozenfeld (1981) Corrosion inhibition of thiourea and thiadiazole derivatives, McGraw-Hill Inc., p.97138.

[3] O.Benali, L.Larabi, M.Traisnel, L.Gengembre, Y. Harek (2007) Electrochemical, theoretical and XPS studies of 2-mercapto-1-methylimidazole adsorption on carbon steel in $1 \mathrm{M} \mathrm{HClO}$, Appl. Surf. Sci., 253, 6130- 6139.

[4] S.Merah, L.Larabi, O.Benali, Y.Harek (2008) Green corrosion inhibitor: inhibitive action of aqueous extract of Anacyclus pyrethrum L. for the corrosion of mild steel in $0.5 \mathrm{M} \mathrm{H}_{2} \mathrm{SO}_{4}$, Pigm.Resin.Technol., 37 (5), 291-298.

[5] O.Benali, L.Larabi, Y.Harek (2009) Inhibitive Action of Argan Press Cake Extract on the Corrosion of Steel in Acidic Media, J. Appl. Electrochem., 39, 769-778. 
[6] O.Benali, L.Larabi, Y.Harek (2010) Influence of the 2 Mercapto-1-Methyl Imidazole (MMI) on the Corrosion Inhibition of Mild Steel in $5 \% \mathrm{HCl}$, J. Saud. Chem. Soc., 14 (2), 231-235.

[7] O.Benali, L.Larabi, B.Tabti, Y.Harek (2005) Influence of the Methylene Blue Dye (MBD) on the corrosion inhibition of mild steel in $0.5 \mathrm{M}$ sulphuric acid, Part I: weight loss and electrochemical studies, AntiCorros. Meth. Mat., 52,280-289.

[8] O.Benali, L.Larabi, S.M.Mekelleche, Y.Harek (2006) Influence of the 2-Mercapto-1-Methyl Imidazole (MMI) on the Corrosion Inhibition of Mild Steel in 5\% $\mathrm{HCl}$, J. Mater.Sci., 41,7064-7073.

[9] N.O.Eddy (2009) Inhibitive and adsorption properties of ethanol extract of Colocasia esculenta leaves for the corrosion of mild steel in $\mathrm{H}_{2} \mathrm{SO}_{4}$, International $\mathrm{J}$. Phys. Sci., 4 (4), 165-171.

[10] A.Bouyanzer, B.Hammouti (2004) Corrosion Inhibition of Aqueous Extract of Cocos nucifera Coconut Palm - Petiole Extract from Destructive Distillation for the Corrosion of Mild Steel in Acidic Medium, Pigment and Resin Tech., 33(5), 287-293.

[11] N.O.Eddy, P.Ekwumemgbo, S.A.Odoemelam (2008) Inhibition of the corrosion of mild steel in $\mathrm{H} 2 \mathrm{SO} 4$ by 5-amino-1-cyclopropyl-7-[(3R, $5 S) 3$, dimethylpiperazin-1-YL]-6, 8-difluoro-4-oxo-uinoline3-carboxylic acid (ACPDQC), Int. J. Phys. Sci., 3(11),275-280.

[12] N.O.Eddy, S.A.Odoemelam, N.W.Akpanudoh (2008) Inhibition of the Corrosion of Zinc in $0.01-0.04 \mathrm{M}$ $\mathrm{H}_{2} \mathrm{SO}_{4}$ by Erythromycin, Res. J. Pure Appl. Sci., 4(12), 1963-1970

[13] N.O.Eddy, S.A.Odoemelam (2008) Adsorption and Inhibitive Properties of Clarithromycin for the Corrosion of $\mathrm{Zn}$ in 0.01 to $0.05 \mathrm{M} \mathrm{H}_{2} \mathrm{SO}_{4}$, J. Pure Appl. Chem., 2(12), 132-138

[14] I.Ahamad, M.A.Quraishi (2010) Mebendazole: New and efficient corrosion inhibitor for mild steel in acid medium, Corrosion Sci., 52(2), 651-656.

[15] M.A.Quraishi, J.Shukla (2009) A new and effective corrosion inhibitor for mild steel in hydrochloric acid, Mater. Chem. Phys.,113(2), 685-689.

[16] G.Moretti, F.Guidi, G.Grion (2004) Tryptamine as a green iron corrosion inhibitor in $0.5 \mathrm{M}$ deaerated sulphuric acid, Corros.Sci., 46, 387- 403.

[17] F.C.Giacomelli, C.Giacomelli, M.F.Amadori, V. Schmidt, A.Spinelli (2004) Mater. Inhibitor effect of succinic acid on the corrosion resistance of mild steel: electrochemical, gravimetric and optical microscopic studies, Chem. Phys., 83(1), 124-128.

[18] E.S.Ferreira, C.Giacomelli, F. C.Giacomelli, A.Spinelli (2004) Evaluation of the inhibitor effect of L-ascorbic acid on the corrosion of mild steel, Mater. Chem. Phys., 83(1), 129-134.

[19] E.E.F.El Sherbini (1999) Chemical and Electrochemical Studies of para-Hydroazopyrazolone Derivatives as Corrosion Inhibitors for Mild Steel in Hydrochloric Acid Solutions, Mater.Chem. Phys., 60(3), 286-290.

[20] M.S Morad (2008) Inhibition of iron, corrosion in acid solutions by Cefatrexyl: Behaviour near and at the corrosion potential, Corros.Sci., 50(2), 436-448
[21] M.A.Quraishi, J.Rawat, M.J.Ajamal (2000) Thermodynamics and Electrochemical Investigation of (4-(2- amino-6-(cyclopropylamino)-9H-purin-9-yl) cyclopent-2-enyl) Methanol Sulphate as Green and Effective Corrosion Inhibitor for Mild Steel in $1 \mathrm{M}$ Hydrochloric Acid, J.Apl.Electrochem., 30(6), 745751.

[22] M.Abdallah (2004) Antibacterial drugs as corrosion inhibitors for corrosion of aluminium in hydrochloric solution, Corrosion Sci., 46(8), 1981- 1996.

[23] A.Zaafarany, M.Abdallah (2010) Ethoxylated Fatty Amide as Corrosion Inhibitorsfor Carbon Steel in Hydrochloric Acid SolutionInt, J.Electrochem Sci, 5, 18-28

[24] A.K.Singh, M.A.Quraishi (2010) The effect of some bis-thiadiazole derivatives on the corrosion of mild steel in hydrochloric acid, Corros.Sci., 52, 152-160.

[25] M.S.Morad (2008) Inhibition of iron corrosion in acid solutions by Cefatrexyl: Behaviour near and at the corrosion potential, Corros,Sci., 50, 436-448.

[26] D.Mareci, G.Nemtoi, N.Aelenei, C.Bocanu (2005) The electrochemical behaviour of various nonprecious $\mathrm{Ni}$ and $\mathrm{Co}$ based alloys in artificial saliva, Euro.Cells Mater., 10, 1-7.

[27] I.A.Von Fraunhofer, S.H.Stidham (1991) Effects of fused-ring antibiotics on metallic corrosion. - NCBI, I. Biomed.Eg.,13, 424-428.

[28] N.O.Eddy, S.A.Odoemelam, E.C.Ogoko, B.I.Ita (2010) Inhibition of the Corrosion of Zinc in 0.01 $0.04 \mathrm{M} \mathrm{H} 2 \mathrm{SO} 4$ by Erythromycin, Port. Electrochim. Acta, 28, 15-26.

[29] E.C.Ogoko, S.A.Odoemelam, B.I.Ita, N.O.Eddy (2009) Adsorption and Inhibitive Properties of Clarithromycin for the Corrosion of $\mathrm{Zn}$ in 0.01 to $0.05 \mathrm{M} \mathrm{H} 2 \mathrm{SO} 4$, Port. Electrochim. Acta, 27, 713724.

[30] A.Samide, B.Tutunaru, C.Negrila, I.Trandafir (2011) A General Solid-State Synthesis of ChemicallyDoped Fluorescent Graphene Quantum Dots for Bioimaging and Optoelectronic Applications, A. Maxut, Dig. I.Nanomater. Bios., 6, 663-673.

[31]A.S.Fouda, M.N.EL-Hadded, Y.M.Abdallah (2013) Septazole: Antibacterial drug as green corrosion inhibitor for copper in hydrochloric acid solution, Inter. J. Innov. Res. Sci. Eng. Technol, (12), 70737085.

[32] I.Naqvi, A.R.Saleemi, S.Naveed (2011) Cefixime: A drug as Efficient Corrosion Inhibitor for Mild Steel in Acidic Media. Electrochemical and Thermodynamic Studies., Inter. J. Electrochem. Sci., 6, 146-161.

[33] C.K.Emereg Ül. M.Hayval (2006) Tobacco Plant Extracts as Save Corrosion Inhibitor for Carbon Steel in Hydrochloric Acid Solutions, Corros.Sci, 48, 797-812.

[34] P.O.Ameh, N.O.Eddy (2013) Commiphora pedunculata gum as a green inhibitor for the corrosion of aluminium alloy in $0.1 \mathrm{M} \mathrm{HCl}$, Res.Chem.Intermediates, p.1-9.

[35] A.S.Fouda, A.A.Al-Sarawy, E.E.El-Katori (2006) Pyrazolone derivatives as corrosion inhibitors for Csteel in hydrochloric acid solution, Desalination, 201, 1-13 
[36] G. Gece (2008) The use of quantum chemical methods in corrosion inhibitor, Studies Corros. Sci., 50, 2981-2992

[37] L.Tang, X.Lie, Y.Si, G.Mu, G.Liu (2006) Mater.hermodynamic study of metal corrosion and inhibitor adsorption processes in mild steel/1 methyl-4[4 (-X)-styryl pyridinium iodides/ hydrochloric acid systems, Chem. Phys., 95, 29-35.

[38] L.Tang, G.Murad, G.Liu (2003) Thymol blue as corrosion inhibitor for carbon steel in $1 \mathrm{M}$ hydrochloric acid solutions, Corros. Sci., 45, 2251 2262

[39] I.N.Putilova, S.A.V.P.Balzin (1960) Oxazole Derivatives as Corrosion Inhibitors for 316L Stainless Steel in Sulfamic Acid Solutions Metallic corrosion Inhibitors, Pergamomon Press, p.31.

[40] E. Khamis (1990) Effect of temperature on the acidic dissolution of steel in the presence of inhibitors, Corrosion (NACE), 46, 476-484.

[41] X.Li, L.Tang (2005) Highly Efficient Corrosion Inhibition of Carbon Steel in Aggressive Acidic Media with a Pyridazinium-based Ionic Liquid, Mater.Chem. Phys., 90, 286-297

[42]S.S.Abd El-Rehim, H.H.Hassan, M. Amin (2001) Dodonaea viscosa (L.) Leaves extract as acid Corrosion inhibitor for mild Steel - A Green approach, Mater.Chem. Phys.,70, 64-72

[43] A. K Singh, M.A. Quraishi (2010) The effect of some bis-thiadiazole derivatives on thecorrosion of mild steel in hydrochloric acid, Corros. Sci., 52, 1373 1385
[44] F. Bentiss, C. Jama, B. Mernari, H. E. Attari, L. E. Kadi, M. Lebrini, M. Traisnel, M. Lagrenee (2009) Inhibition Effect of Cefradine on Corrosion of Mild Steel in HCl Solution, Corros.Sci.,51, 1628-1635

[45] H.Ashassi-Sorkhabi, D.Seifzadeh, M.G.Hosseini (2008) Inhibition Effect of Cefradine on Corrosion of Mild Steel in HCl Solution, Corros. Sci., 50, 33633370

[46] A.Popova, M.Christov (2006) Evaluation of impedance measurements on mild steel corrosion in acid media in the presence of heterocyclic compounds, Corros. Sci., 48, 3208-3221

[47] Gamry Echem Analyst Manual (2003) Oxazole Derivatives as Corrosion Inhibitors for $316 \mathrm{~L}$ Stainless Steel in Sulfamic Acid Solutions.

[48] R.W.Bosch, J.Hubrecht, W.F.Bogaerts, B.C.Syrett (2001) Electrochemical Frequency Modulation: A New Electrochemical Technique for Online Corrosion Monitoring, Corrosion, 57, 60-70

[49] S.S.Abdel-Rehim, K.F.Khalid, N.S.Abd-Elshafi (2006) Chemical and lectrochemical Investigations of L- Arginine as Corrosion Inhibitor for Steel in Hydrochloric Acid Solutions, Electrochim. Acta, 51, 3269-3277

[50] A.K.Singh, M.A.Quraishi (2010) A Green Corrosion Inhibitor for Steel in Concrete Environment, J. Mater. Environ. Sci ., 1, 101-110

\section{IZVOD}

\section{NEOBIČNO KORIŠĆENJE LEKA AUGMENTIN KAO INHIBITORA KOROZIJE $\alpha$-MESINGA U RASTVORU $\mathrm{HNO}_{3}$}

Nekorišćeni lek Augmentin je ispitivan kao inhibitor korozije $\alpha$-mesinga u rastvoru azotne kiseline različitim tehnikama praćenja. Rezultati su pokazali da postoje varijacije u inhibiciji pri korišćenju leka pri različitim koncentracijama i temperaturama. Maksimalna efikasnost od $93.6 \%$ je dobijena pri koncentraciji od 300ppm leka, pri temperaturi od $40^{\circ} \mathrm{C}$ i pri potapanju od 3 sata. Temkinova izoterma je korišćena da opiše adsorpciju leka na površini $\alpha$-mesinga. Potenciodinamička ispitivanja su pokazala da ovaj lek deluje kao mešoviti tip inhibitora. Rezultati elektrohemijske impedance pokazali su smanjenje kapacitivnosti dvojnog sloja i povećanje otpornosti prenosa naelektrisanja. Mehanizam hemijske adsorpcije je predložen na osnovu izračunatih termodinamičkih parametara za ispitivani lek. Rezultati ispitivanja različitim tehnikama pokazali su dobre međusobne uporedne podatke.

Ključne reči: Inhibicija korozije, $\alpha$-mesing, lek augmentin, Temkinova izoterma, $\mathrm{HNO}_{3}$.

\section{Naučni rad}

Rad primljen: 19. 03. 2016.

Rad prihvaćen: 27. 04. 2016.

Rad je dostupan na sajtu: www.idk.org.rs/casopis 